\title{
Fermentation characteristics of mulberry (Cudrania tricuspidata) fruit vinegar produced by acetic acid bacteria isolated from traditional fermented foods
}

\author{
Eun-Jung Yim ${ }^{1}$, Seung-Wha Jo ${ }^{1}$, Eun-Sil Lee ${ }^{1}$, Hae-Suk Park ${ }^{1}$, Myeong-Seon Ryu ${ }^{2}$, \\ Tai-Boong Uhm ${ }^{2}$, Hyoun-Young $\mathrm{Kim}^{3}$, Sung-Ho Cho ${ }^{1 *}$ \\ ${ }^{1}$ Micrbial Institute for Fermentation Industry, Sunchang 595-804, Korea \\ ${ }^{2}$ Department of Biological Sciences, Chonbuk National University, Jeonju 561-756, Korea \\ ${ }^{3}$ Institue of Sunchang Fermented Soybean Products, Sunchang 595-805, Korea
}

\section{전통발효식품으로부터 분리한 초산균을 이용한 꾸지뽕 열매 발효식초 제조 및 발효특성}

\author{
임은정 ${ }^{1} \cdot$ 조승화 ${ }^{1} \cdot$ 이은실 ${ }^{1} \cdot$ 박해석 $^{1} \cdot$ 류명선 $^{2} \cdot$ 엄태붕 ${ }^{2} \cdot$ 김현영 $^{3} \cdot$ 조성호 ${ }^{1 *}$ \\ ${ }^{1}$ (재)발효미생물산업진흥원, ${ }^{2}$ 전북대학교 자연과학대학 생명과학과, ${ }^{3}$ 순창군 장류사업소
}

\begin{abstract}
To raise the added value of the fruits of Cudrania tricuspidata, Cudrania tricuspidata vinegar was produced and examined for its fermentation conditions. Forty nine acetic acid bacteria with resistance against acetic acid, ethanol, and sulfide as high acetic acid producers were isolated from fermented foods and identified as Acetobacter indonesiensis, A. cerevisiae, A. orientalis, $A$. tropicalis, $A$. fabarum, $A$. pasteurianus, and $A$. syzygii based on the results of the analysis of the 16S rRNA gene sequences. Among them, two GRAS strains, A. pasteurianus SCMA5 and SCMA6, were finally selected for the production of acetic acid. Optimal vinegar productions were obtained from the medium containing $40 \%$ (v/v) fruit juice of Cudrania tricuspidata and $5 \%(\mathrm{v} / \mathrm{v})$ ethanol at $25{ }^{\circ} \mathrm{C}$ for $72 \mathrm{hr}$. The sensory panel preferred the vinegar fermented with the SCMA06 to that with the SCM05 strain. The radical scavenger capacity of DPPH was 53\% higher than that of the control in the vinegar fermented with the SCMA06 strain. The a-glucosidase inhibitor activity as an index of the antidiabetic drug showed $91 \%$ inhibition, which is higher than that of acabose. This study will be helpful for the scale-up production of vinegar with the fruit of Cudrania tricuspidata.
\end{abstract}

Key words : acetobacter, agricultural resources, Cudrania tricuspidata, fermentation, vinegar

\section{서 론}

양조 식초는 한국인의 식단에 오랫동안 사용되어온 기초 조미료로서 당류와 전분을 주원료로 하는 미생물 발효식품 이다. 양조 식초는 효모에 의해 당을 에탄올로 만들고, 초산

*Corresponding author. E-mail : sunghyej3@nate.com Phone : 82-63-653-9578, Fax : 82-63-653-9590

Received 22 September 2014; Revised 3 December 2014; Accepted 14 January 2015.

Copyright (c) The Korean Society of Food Preservation. All rights reserved.
세균을 사용하여 에탄올을 초산으로 산화시킨 뒤 숙성시키 는 과정으로 제조된다. 이 공정 동안 효모와 초산균은 초산 이외에 각종 휘발성 및 비휘발성 물질인 당, 유기산, 아미노 산, 고급 알코올, 에스테르 등을 생산하여 양조 식초 특유의 풍미와 감미 특성을 나타낸다.

양조 식초는 발효 기술에 기반을 두었기 때문에 이미 장류, 김치 등의 세계적 발효 식품들을 생산해온 국내에서 도 중국 샨시 숙성식초, 이탈리아의 발사믹 식초, 일본의 흑초와 같은 명품 식초를 개발하는 것이 가능할 것이다. 지금까지 일반 조미용 식초는 주정을 원료로 제조되어 풍미 의 다양성을 느낄 수 없었지만 최근 들어 천연 원료를 사용 
하는 전통 제조 방식의 건강용, 기능용 식초가 소규모 시장 을 형성하기 시작했다. 식초를 발효하는데 가장 중요한 요 소는 미생물로서, 균주에 따른 다양한 대사를 고려할 때 이들이 식초의 독특한 향과 맛을 결정한다. 양조용 초산 세균은 Acetobacteraceae family에 속하며, 현재까지 Acetobacter, Gluconobacter, Gluconacetobacter 등의 12속 (genus)이 보고되어 있다(1-3). 국내의 초산균 연구는 농업 자원의 부가가치를 높이기 위해 감(4), 유자(5), 산딸기(6), 사과(7), 오미자(8), 감귤(9)을 발효한 식초를 이용하여 제조 하였고, 이들 과일 또는 채소 식초에서 동정했던 발효균들 은 Acetobacter 속의 균들이었다. 하지만 국내에서 수집한 전통 식초 내 미생물 군집 구성 및 이들의 분포는 아직까지 보고된 바 없다. 이들 중 Acetobacter 속은 알코올 내성이 크고 초산 내성이 강하여 산업적으로 가장 중요한 식초 생산균 $(1,10)$ 이며, 현재 식약처의 양조 식초용 GRAS (generally recognized as safe) 균주로는 유일하게 Acetobacter pasteurianus 만이 허가되어 있다.

양조 식초의 제조를 위하여 우리는 국내에서 제조한 막 걸리, 누룩, 전통 제조 방식의 곡물 및 과일 식초들로부터 초산균의 분리를 시도하였다. 전통 발효식품에서 초산균의 분리는 2014년 10월 나고야 의정서가 발효됨에 따라 지불 해야하는 로열티 지급에서도 자유로울 수 있으며, 토종 균 주들의 국가적 자원화에도 중요하다. 또한 지역마다 고유 한 가양주와 함께 사라졌던 전통 식초의 복원을 위해서도 초산 균주의 분리는 필요한 과제이다. 이와 함께 순창 지역 10 대 특산품으로 항당뇨(11), 골다공증 억제(12), 항암(13), 항염증 능력(14)이 알려진 꾸지뽕 열매를 사용하여 지역 농업 자원의 이용성과 식초의 기능성을 높이고자 하였다. 이 연구는 식초용 토종 균주들을 동정하고 이들 중 산업적 가능성이 높은 균주를 선발함으로서 전통식 식초에서 문제 되는 위생 문제를 해결하고, 동시에 풍미 및 기능성을 만족 할 수 있는 과일 식초를 제조하는데 목표를 두었다.

\section{재료 및 방법}

\section{실험재료}

꾸지뽕 열매 양조식초 제조를 위한 꾸지뽕 열매는 순창 군내에서 구입하여 냉동보관하면서 사용하였다. 토착발효 초산균 분리를 위해서는 전통발효식품인 막걸리 26 개와 전통양조식초 6 개를 구매하여 사용하였다.

\section{초산균주의 분리}

막걸리는 초산발효가 일어나도록 실온에서 약 14 일 보관 후 식초냄새가 날 때 사용하였고, 식초는 실온에서 보관하 였다가 실험에 사용하였다. 각 시료를 GYE배지(1\% yeast extract(Difco Laboratories, Detroit, MI, USA), 5\% glucose
(Sigma Chemical Co., St. Louis, MO, USA), 3\% ethanol (Sigma Chemical Co., St. Louis, MO, USA)로 각각 희석하여 Acetobacter 선택 배지(1\% yeast extract, 5\% glucose, 3\% ethanol, 3\% $\mathrm{CaCO}_{3}($ Sigma Chemical Co., St. Louis, $\mathrm{MO}$, USA), 2.5\% agar(Difco Laboratories, Detroit, MI, USA, 0.1\% cycloheximide(Sigma Chemical Co., St. Louis, MO, USA), $0.05 \%$ penicillin)에 $200 \mu \mathrm{L}$ 를 도말하여 $27^{\circ} \mathrm{C}$ 에서 2 일간 배 양한 후 콜로니 주위로 투명한 환이 생긴 콜로니를 선발하 였다.

\section{초산내성 및 초산 고생산 능력}

Acetobacter 선택 배지에서 선발한 균주를 초산 내성 및 초산 고생산 능력을 확인하기 위해 $\mathrm{GYEC}$ 배지 $(1 \%$ yeast extract, $5 \%$ glucose, $3 \%$ ethanol, $3 \% \mathrm{CaCO}_{3}, 2.5 \%$ agar)에 tooth pick로 접종하여 $27^{\circ} \mathrm{C}$ 에서 2 일간 배양하여 콜로니 크기와 균주가 만들어낸 초산으로 인하여 생긴 투명환의 크기를 측정하고, 콜로니의 크기를 측정하였다. 투명환의 크기를 콜로니의 크기로 나누어 상대적인 값을 구하여 $3 \%$ ethanol에서 초산 생산 능력을 확인하였다.

총산도

배양액을 증류수로 20 배 희석한 후 $1 \%$ phenolphthalein (Sigma Chemical Co., St. Louis, MO, USA) $40 \mu \mathrm{L}$ 를 첨가한 후 30초 동안 붉은색을 띨 때까지 $0.1 \mathrm{~N} \mathrm{NaOH}$ 를 $50 \mu \mathrm{L}$ 씩 첨가하였다. 중화 적정에 첨가된 $0.1 \mathrm{~N} \mathrm{NaOH}$ (Daejung Chemical, Suwon, Korea)소비량 $(\mathrm{mL})$ 으로 총 산도를 계산하 였다.

$$
\text { 총산도 }(\%)=\frac{(0.1 \mathrm{~N} \mathrm{NaOH} \text { 적정량 }(\mathrm{mL}) \times \text { 계수 }(0.0063) \times \text { 희석배수 }(20)}{\text { 시료량 }(\mathrm{mL})} \times 100
$$

초산 분석

정량적인 초산 생산량을 확인하기 위하여 총 산도가 높 게 나온 균주의 배양액 중 acetic acid 함량을 분석하였다. 균주를 $10 \%$ 의 ethanol로 조정된 GYE배지(1\% yeast extract, $5 \%$ glucose, $10 \%$ ethanol)에 접종하여 $27^{\circ} \mathrm{C}$ 에서 $170 \mathrm{rpm}$ 으 로 3 일간 진탕배양 하였다. 배양액 $1 \mathrm{~mL}$ 을 $13,000 \mathrm{rpm}$ 에서 10 분간 원심분리 한 후 $500 \mu \mathrm{L}$ 를 취해 $0.45 \mu \mathrm{m}$ filter로 균체 를 완전히 제거한 후 최종 시료로 사용하였다. HPLC 조건 은 Table 1 과 같으며 시료 주입 후 표준물질 acetic acid의 머무름 시간을 확인하고, 주입한 시료의 peak 면적 값을 표준 acetic acid 곡선과 비교하여 acetic acid의 양을 계산하 였다.

\section{Ethanol 내성}

선발된 균주가 ethanol에 내성을 가지고 있는지 확인하기 위하여 $\mathrm{GYEC}$ 배지에 각각 $10,12,15,20 \%$ 의 ethanol 농도로 조정하여 tooth pick로 균주를 접종하고 $27^{\circ} \mathrm{C}$ 에서 4 일간 
배양하였다. 투명환의 크기와 콜로니의 크기를 측정 한 후 투명환의 크기를 콜로니의 크기로 나누어 상대적인 값을 구하여 $10,12,15,20 \%$ ethanol에서 초산 생산 능력을 확인 하였다.

Table 1. HPLC analysis

\begin{tabular}{cl}
\hline HPLC & \multicolumn{1}{c}{ Gilson 307 piston pump } \\
\hline Column & Alltech IOA-1000 oragnic acids column \\
& $7.8 \times 300 \mathrm{~mm}$ (I.D. ×Length), $9 \mu \mathrm{m}$ \\
Detector & Gilson 118 UV/VIS detector \\
Wave length & $210 \mathrm{~nm}$ \\
Mobile phase & $0.005 \mathrm{~N}$ Sulfuric acid \\
Flow rate & $0.3 \mathrm{~mL} / \mathrm{min}$ \\
Sample injection volume & $100 \mu \mathrm{L}$ \\
\hline
\end{tabular}

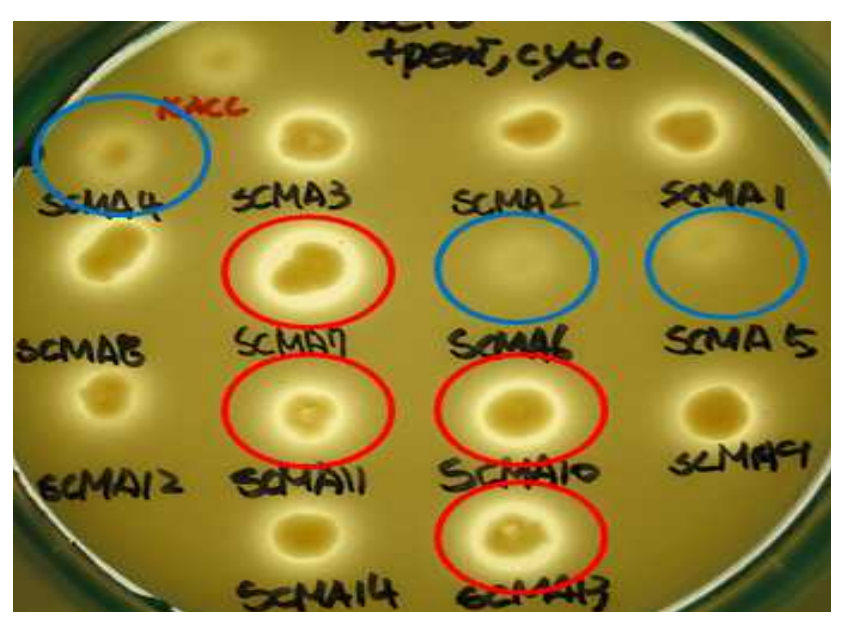

Fig. 1. Clear zone of colonies in the GYEC medium with $3 \%$ ethanol. Blue circle, strain with low acetic acid production; red circle, strain with high acetic acid production.

아황산염(sulfite) 내성

선발한 균주들 중 아황산염에 내성이 있는 균주를 확인 하기 위하여 GYEC배지에 potassium metabisulfite $\left(\mathrm{K}_{2} \mathrm{~S}_{2} \mathrm{O}_{5}\right.$, 메타중아황산칼륨)을 첨가하여 실험을 수행하였다. CODEX (국제식품규격위원회)에서는 아황산 사용기준을 $350 \mathrm{ppm}$ 이하로 규정하고 있어 본 실험에서는 GYEC배지에 350 $\mathrm{ppm}$ 의 potassium metabisulfite를 첨가하였다. 아황산 내성 확인 배지 (1\% yeast extract, $5 \%$ glucose, $15 \%$ ethanol, $3 \%$ $\mathrm{CaCO}_{3}, 2.5 \%$ agar, $350 \mathrm{ppm}$ potassium metabisulfite)에 tooth pick로 균주를 접종하고 $27^{\circ} \mathrm{C}$ 에서 8 일 배양한 후 투명환의 크기와 콜로니의 크기를 측정한 후 투명환의 크기를 콜로니 의 크기로 나누어 상대적인 값을 구해 $350 \mathrm{ppm}$ 의 아황산에 내성을 가지고 균주를 확인하였다.

\section{균주 동정}

선발된 균주의 $16 \mathrm{~S}$ rRNA 유전자 염기서열에 의한 균
동정을 위해 universal primer로서 27F(5'-AGAGTTTG ATCCTGGCTCAG - 3)와 1492R(5'-GGTTACCTTGTTA CGACTT - 3')을 사용하여 $16 \mathrm{~S}$ rRNA 유전자를 증폭 후, Big Dye Terminator v3.1 Cycle Sequencing kit(Applied Biosystems Inc., USA)를 이용하여 염기서열을 해독하였다. 이 염기서열들을 이용해서 BLASTN search(15)와 Ribosomal Database Project(version 11)의 SeqMatch program에서 서열 일치도가 높은 표준 균주들의 $16 \mathrm{~S} \mathrm{rRNA}$ 유전자 염기서열 들을 얻었고, 이들 염기 서열간의 상호비교를 위해 CLUSTAL W(16)를 사용하였다. 계통도 분석은 균주들의 $16 \mathrm{~S}$ rRNA유전자 염기 서열들을 정렬하고 chromatogram의 시각적 관찰과 수작업으로 gap이 최소화되도록 보정한 후 Tamura-Nei model에 기초한 Maximum Likelihoood 방법 (17)을 사용하여 작성하였다. 산출한 각각의 계통수에서 각 분지에 대한 통계학적 신뢰도를 산출하기 위해 bootstrap 분석을 1,000 회 실행하였으며, 계통분석과 bootstrap 분석 은 MEGA program(17)를 사용하였다.

\section{초산 발효 조건 확립}

냉동 꾸지뽕 열매는 마쇄하여 즙액 $(\mathrm{pH} 5.45$, 산도 $0.3 \%$ $\left.17.5^{\circ} \mathrm{Brix}\right)$ 을 수거하여 사용하였다. 꾸지뽕 열매 $100 \%$ 원액 을 사용하여 증류수와 희석한 후 멸균하여 $5 \mathrm{~mL}$ 초산균 발효용 영양원으로 사용하였다. 선발된 초산균은 $\mathrm{GYE}$ 배지 ( $1 \%$ yeast extract, $5 \%$ glucose, $5 \%$ ethanol)에서 전 배양하여 활성화시킨 후 사용하였다.

초산발효조건 확립을 위한 실험에서는 꾸지뽕 열매 즙액 의 농도를 결정하기 위해 냉동꾸지뽕 열매의 농도 $(1,5$, $10,20,30,40,50 \%(\mathrm{v} / \mathrm{v}))$ 별로 ethanol 농도를 $5 \%$ 로 조정한 후 $25^{\circ} \mathrm{C}$ 에서 $200 \mathrm{rpm}$ (Shaking incubator, VS-8480SF, Vision scientific, Wonju, Korea)으로 72시간 동안 배양하면서 $\mathrm{pH}$ 를 측정하였다. 발효온도 조건은 꾸지뽕 열매 즙액 $5 \%$ 와 ethanol $5 \%$ 가 되도록 한 후 발효온도 $\left(25,35,45^{\circ} \mathrm{C}\right)$ 를 달리하 여 $200 \mathrm{mpm}$ 에서 72시간 동안 배양하면서 $\mathrm{pH}$ 를 측정하였다. ethanol 농도는 꾸지뽕 열매 즙액 $5 \%$ 에 ethanol 농도 $(5,10$, $20 \%(\mathrm{v} / \mathrm{v})$ )별로 구간을 설정하여 $25^{\circ} \mathrm{C}$ 에서 $200 \mathrm{rpm}$ 으로 72 시간 동안 배양하면서 $\mathrm{pH}$ 를 측정하였다.

관능평가

꾸지뽕열매를 이용한 발효액의 관능평가는 발효미생물 산업진흥원과 한국절임 직원 25 명을 대상으로 실시하였다. 평가항목은 신맛을 제외한 색, 향, 전체적 기호도는 5 점 채점법으로 평가하였으며, 신맛은 특성 강도에 따라 5 점 채점법으로 평가하였다.

\section{기능성 특성}

초산균을 이용하여 최종 제조한 발효물에 대하여 항산 화, 항당뇨 기능성을 평가하였다. 이때 발효물을 $0,24,48$, 
72 시간 주기로 샘플링하여 냉동실에 보관하여 사용하였고, 발효액은 $10,000 \mathrm{rpm}$ 에서 20 분간 원심분리한 후 $0.45 \mu \mathrm{m}$ 실린지 필터( $0.2 \mu \mathrm{m}$, Satorius, Germany)를 이용하여 제균한 후 시험에 사용하였다.

\section{$\mathrm{DPPH}$ 라디칼 소거능 측정}

$\mathrm{DPPH}$ 에 의한 자유라디칼 소거활성은 Blois의 방법(18) 을 약간 변형하여 측정하였다. 시료 $50 \mu \mathrm{L}$ 에 $0.15 \mathrm{mM} \mathrm{DPPH}$ 용액(99\%(v/v) MeOH에 용해) $150 \mu \mathrm{L}$ 을 가한 후 30분간 상온에서 방치한 후, 분광광도계(elisa reader, Infinite 200 TECAN, Austria) 사용하여 흡광도 $517 \mathrm{~nm}$ 에서 흡광도의 변화를 측정하였다. 각 시료의 라디칼 소거능은 하기 식(1) 에 의해 시료 첨가구 및 무첨가구 사이의 흡광도 차이를 백분율(\%)로 나타내었다.

DPPH radical scavenging activity $(\%)=[1-(\mathrm{A} / \mathrm{B})] \times 100$

\section{A : Absorbance of sample \\ B : Absorbance of blank}

\section{a-Glucosidase inhibition(AGI) 활성}

AGI 활성은 Watanabe 등(19)의 방법을 약간 변형하여 측정하였다. 시료 $50 \mathrm{uL}$ 에 $0.5 \mathrm{U} / \mathrm{mL}$ a-glucosidase 효소액 $50 \mu \mathrm{L}$ (in 0.1M PBS, pH 6.8)을 혼합하여 $37^{\circ} \mathrm{C}$ 에서 10 분 동안 pre-incubation하였다. $3 \mathrm{mM}$ p-NPG( $\rho$-nitro-phenyl-a -glucopyranoside, in 0.1 M PBS, pH 6.8) $100 \mu \mathrm{L}$ 를 가한 후 $37^{\circ} \mathrm{C}$ 에서 10 분간 반응시킨 후 $0.1 \mathrm{M} \mathrm{Na}_{2} \mathrm{CO}_{3} 100 \mathrm{uL}$ 를 가하여 반응을 정지시켰다.

이때 생성된 $\rho$-nitrophenol의 양을 분광광도계(elisa reader, Infinite 200 TECAN)를 사용하여 흡광도 $405 \mathrm{~nm}$ 에 서 측정하였다. 대조구는 배양액 대신 $0.1 \mathrm{M} \mathrm{PBS}(\mathrm{pH} 6.8)$ 을 사용하였으며, 기준 값(blank)은 균주 배양액 및 효소액 대 신 $0.1 \mathrm{M} \mathrm{PBS}(\mathrm{pH} 6.8)$ 을 사용하였다. 각 시료의 AGI 활성은 다음 식에 의해 시료 반응구와 무처리구 사이의 흡광도 차이를 백분율(\%)로 나타내었다.

AGI activity $(\%)=\{1-(\mathrm{As}-\mathrm{Ab}) / \mathrm{Ac}\} \times 100$

As : Absorbance of the sample

$\mathrm{Ab}$ : Absorbance without addition of the enzyme

Ac : Absorbance without addition of the sample

\section{이화학적 특성}

꾸지뽕열매 초산균 발효액의 품질특성은 $\mathrm{pH}$, 산도, 당도, 미생물 생육정도를 파악하였으며, $\mathrm{pH}$, 산도는 자동적정장 치(Excellence Titrator T50M, Switzerland), 당도는 디지털당 도계(PAL-1, Atago, Tokyo, Japan)를 이용하여 분석하였다.

\section{미생물학적 특성}

미생물학적 특성 분석 항목인 세균수, 진균수(곰팡이, 효모)는 시료 $10 \mathrm{~g}$ 을 멸균한 식염수에 넣어 교반한 후 희석 해서 페트리필름(Petrifilm ${ }^{\mathrm{TM}}$ aerobic count, yeast and mold count; 3M, USA)를 이용하여 시험하였고, 식중독 미생물 분석은 식품공전법(고시 2011. 10. 14)에 준하여 실시하였 다.

\section{통계처리}

실험결과 중 DPPH radical 소거능 활성과 a-Glucosidase inhibition(AGI) 활성은 Minitab 16 statistical program을 이용 하여 one-way ANOVA 분석 수행하였고, 평균값의 통계적 유의성은 $\mathrm{p}<0.05$ 수준에서 검정하였다.

\section{결과 및 고찰}

\section{초산균주의 선발}

막걸리 26종, 전통발효식초 6종로부터 acetobacter의 선 택배지인 GYEC 배지(3\% 에탄올 함유)를 이용하여 초산 생성균주로 추정되는 48 개의 집락을 1 차로 선발하였다. 이 과정에서 초산 균주만을 분리하기 위해 GYE 배지에 효모 와 곰팡이 증식을 억제하는 cycloheximide와 일반 다른 세 균의 증식을 억제하는 penicillin을 첨가하였으며, 초산과 반응하여 투명환을 형성하는 백색의 $\mathrm{CaCO}_{3}$ 를 넣고 집락 주위에 생성된 투명환 크기와 투명도를 비교하였다(Fig. 2). 이 방법은 초산 세균의 선택적 분리에 매우 유용하여 선발 48 균주들을 $16 \mathrm{~S} \mathrm{rRNA}$ 유전자 염기 서열 분석에 의한 동정 결과, 모두 acetobacter 속으로 동정되었다(Fig. 4). 양 조식초 발효에 실질적으로 적용할 수 있는 에탄올 내성 균을 선발하기 위하여 48 균주들 중 2차로 총산도가 높았던 13 균주를 골라 GYE 고체 배지에 에탄올을 각각 $10 \%$,

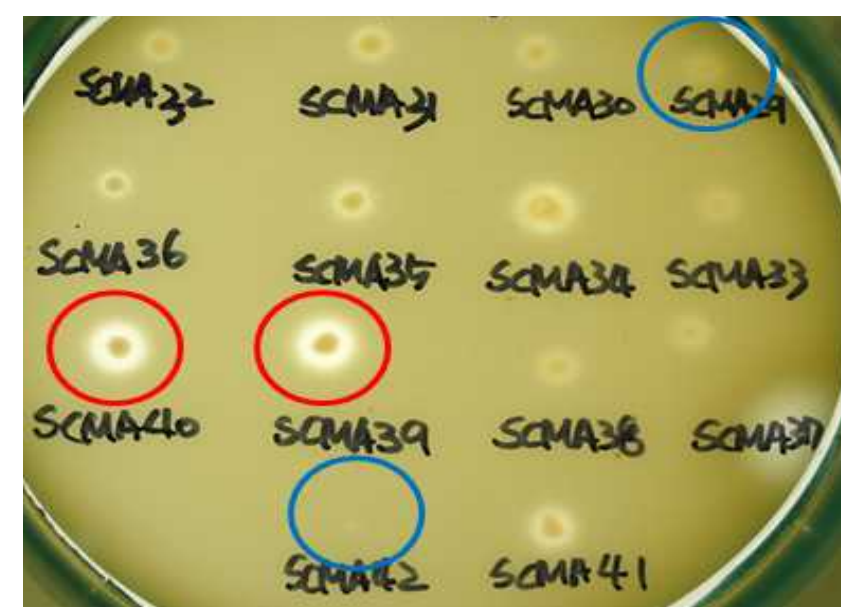

Fig. 2. Clear zone of colonies in the GYEC medium with $20 \%$ ethanol. Blue circle, strain without $20 \%$ ethanol tolerance; red circle, strain with $20 \%$ ethanol tolerance. 
$12 \%, 15 \%, 20 \%$ 첨가한 뒤 배양하여 투명환 비율을 정량하 였다. 이들 중 $20 \%$ 에탄올에 내성을 지닌 균주는 배양 결과 SCMA05, SCMA06, SCMA17, SCMA39, SCMA40의 5종이 었다(Fig. 2). 그러나 선발 균주들의 액체 배양에서는 에탄 올이 $15 \%$ 이상이 함유된 배지에서 증식이 저해되었기 때문 에, $10 \%$ 에탄올이 첨가된 $\mathrm{GYE}$ 액체 배양액에서 초산 생성 능을 비교하였다. 이들 중 초산 생성능은 SCMA05와 SCMA06 균주가 $6.18 \%$ 및 $6.83 \%$ 로 다른 균주들에 비해 약 1.5-6배 더 높았으며, 에탄올로부터 초산 전환율(에탄올 $1 \mathrm{~mol}$ 에서 초산 $1 \mathrm{~mol}$ 이 생성될 때 이론적 전환율은 $100 \%)$ 은 각각 $47.4 \%$ 와 $52.4 \%$ 였다. 상업적 과일주 제조는 일반적 으로 과육 껍질에 존재하는 효모나 잡균을 아황산염 $\left(\mathrm{K}_{2} \mathrm{~S}_{2} \mathrm{O}_{5}\right.$ 또는 $\left.\mathrm{Na}_{2} \mathrm{~S}_{2} \mathrm{O}_{5}\right)$ 으로 제거한 뒤 스타터를 첨가하여 발효하며, 이 아황산염은 최종 숙성 제품에서도 잔류한다. 과일주로 제조하는 식초 제조의 경우 아황산염에 내성이 있는 초산균주가 필요하여 13 균주를 대상으로 potassium metabisulfite를 $350 \mathrm{mg} / \mathrm{L}$ 를 첨가한 $\mathrm{GYE}$ 고체 배지에 배양 하였다. 그 결과 13 균주 모두 아황산염에 저항을 보여 아황 산을 첨가된 과일주에서도 이들 초산균은 생존할 수 있을 것으로 보인다(Fig. 3).

선발된 49개 균주를 $16 \mathrm{~S}-\mathrm{rRNA}$ 유전자 염기서열 분석 방법에 따라 동정한 결과는 Fig. 4와 같다. 동정 결과 Acetobacter indonesiensis가 19종으로 가장 많았으며, $A$ cerevisiae 9종, $A$ orientalis 7종, $A$ tropicalis 7종, $A$ fabarum 3종, $A$ pasteurianus 2종 및 $A$ syzygii 1종으로 동정되었다. 이러한 결과는 재래식 과일 식초에서 분리한 초산균들이 Acetobacter 속에 속한다는 동정 결과들과 잘 일치하였으며 $(15,20)$, 특이하게도 일반적으로 발견되는 초산균인 Gluconobacter나 Gluconacetobacter 가 아직까지 전통 식초 제품에서 보고된 바 없다는 것은 흥미로운 사실이다. 현재 식약처가 초산 제조용 GRAS 균주로 유일하게 $A$ pasteurianus

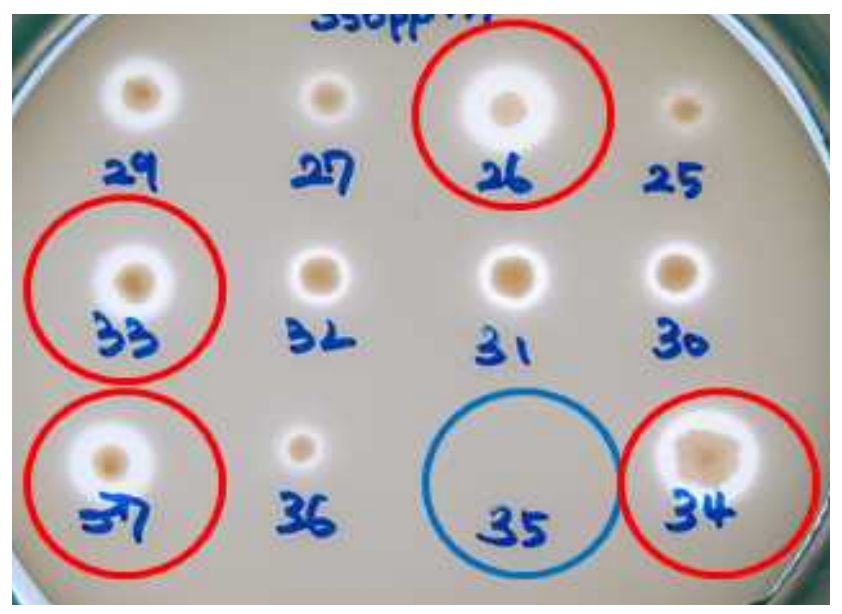

Fig. 3. Clear zone of colonies in the GYEC medium with $350 \mathrm{ppm}$ potassium metabisulfite. Blue circle, strain without $350 \mathrm{ppm}$ potassium metabisulfite tolerance; red circle, strain with $350 \mathrm{ppm}$ potassium metabisulfite tolerance.
만을 인정하고 있으므로, 초산 및 향미 생성이 우수한 다른 Acetobacter 속 균주들도 유전체 분석을 통해 안전성 문제를 확보해야 할 것이다. 이를 규명하기 위하여 앞으로 전통 방식으로 조제한 식초들을 대상으로 미생물군집 구조에 대한 체계적 분석을 하여 주요 초산 균주들을 모니터링을 하고, 이들 중 상업적으로 가치가 있는 균주에 대해 유전체 분석 및 그 기능이 확인이 필요하다.

양조식초 제조에 적합한 초산균의 선발기준은 초산 생산 량이 많고, ethanol에 내성이 강하고, 아황산염에 내성이 강한 균주를 기본으로 하여, SCMA3(Acetobacter tropicalis), SCMA5(Acetobacter pasteurianus), SCMA6(Acetobacter pasteurianus), SCMA16(Acetobacter tropicalis), SCMA18 (Acetobacter tropicalis), SCMA19(Acetobacter tropicalis) 균 주, 총 6종의 균주를 선발할 수 있었다(Table 2). 6종 중에서 식품의약품안전처에서 식초제조에 종균으로 이용할 수 있 는 초산균은 $A$ pasteurianus만 허가되어 있어 꾸지뽕 열매 를 활용한 양조식초 제조 연구에는 SCMA5와 SCMA6을 대상으로 하였다.

\section{초산 발효조건}

꾸지뽕열매 즙액 농도를 $1,5,10,20,30,40$ 및 $50 \%(\mathrm{v} / \mathrm{v})$ 로 하여 초산균을 각각 접종한 후 $\mathrm{pH}$ 를 분석한 결과, 발효 0시간째는 4.3 5.1이었으며, 배양 72시간후에 3.3 3.5를 나타내었다(Fig. 5). 초기 $\mathrm{pH}$ 는 꾸지뽕 즙액 농도의 영향으 로 사료되며, 72 시간째 $\mathrm{pH}$ 는 초기 $\mathrm{pH}$ 의 농도의 관계없이 유사한 결과치를 보여주었다.

배양온도 조건 확립을 위한 시험에서는 $25^{\circ} \mathrm{C}$ 에서 배양한 발효액의 $\mathrm{pH}$ 가 3.35 3.40으로 나타났으며, $\mathrm{pH}$ 를 기준으로 적정 배양온도는 $25^{\circ} \mathrm{C}$ 임을 확인하였다(Fig. 6).

초산 생성에 영향을 미치는 ethanol의 첨가농도에 따른 발효액의 $\mathrm{pH}$ 변화를 확인한 결과, $A$ pasteurianus 2 종의 초산균 모두 5\%(v/v) 농도의 ethanol을 첨가하였을 때 $\mathrm{pH}$ 3.40 수준을 보여주었다. 식초 제조 시 효과적인 초산 생성 을 위하여 첨가된 알코올은 식초 발효가 진행됨에 따라 그 함량이 감소하는 것을 확인하였다(20-22). Kim 등(23)은 유자과즙을 이용한 식초제조 연구에서 식초발효를 위한 1 차 알코올 발효물의 알코올 함량이 7 8\% 일 때, 초기 발효 시간을 단축할 수 있었다고 보고하였다. 하지만 본 연구에 서는 ethanol 농도가 높아질수록 $\mathrm{pH}$ 감소폭이 작게 나타났 는데, 이는 높은 농도의 ethanol에 의해 초산균의 성장이 저해 받은 것으로 사료된다(Fig. 7). 초산균은 호기성이기 때문에 교반함으로써 발효를 촉진시킬 수 있는데, Lee 등 (24)은 참외식초 제조 시 총산도의 최적조건은 교반속도가 $200 \mathrm{rpm}$ 일 때였다고 하였으며, Lee 등(25)은 감자를 이용한 식초 제조 시 교반속도가 150 200 rpm일 때 높은 총산을 나타내었다고 보고하였을 뿐만 아니라, Shin 등(26)도 당근 식초 제조 시 초산발효액을 정치 배양할 때보다 진탕 배양 


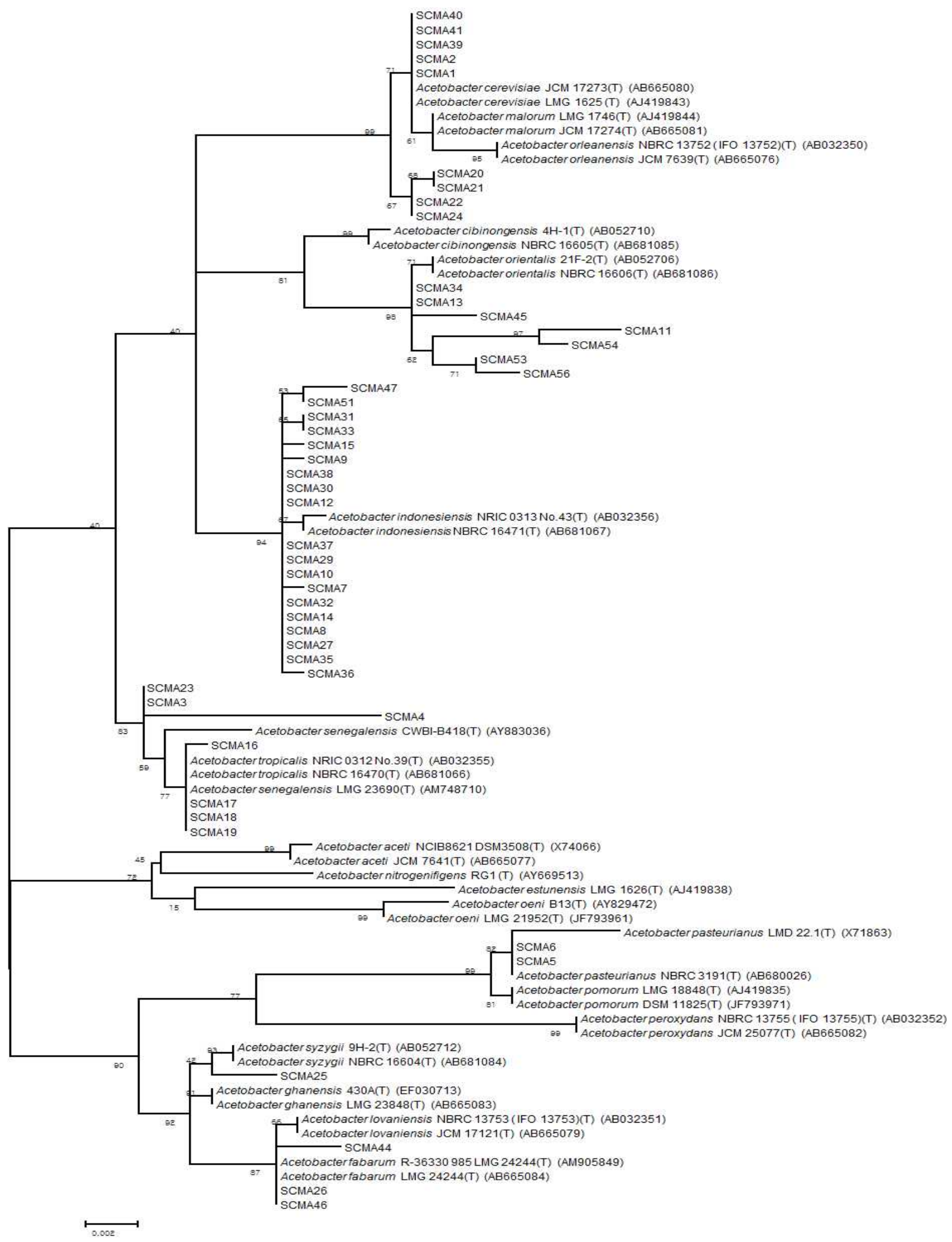

Fig. 4. Molecular phylogenetic analysis of the strains isolated from makgeolli and traditional vinegar through the maximum Likelihood method based on the 16S rRNA gene sequences. 
Table 2. Experimental data on the ethanol toler ance, acetic acid content, total acidity, and potassium metabisulfite tolerance of the acetic acid bacteria isolated from traditional fermented food

\begin{tabular}{|c|c|c|c|c|c|c|c|}
\hline \multirow[t]{2}{*}{ No. } & \multicolumn{4}{|c|}{$\begin{array}{c}\text { Ethanol tolerance } \\
\text { (halo size/colony size, } \mathrm{cm} \text { ) }\end{array}$} & \multirow[t]{2}{*}{ Acetic acid content $(\%)$} & \multirow{2}{*}{ Total acidity(\%) } & \multirow{2}{*}{$\begin{array}{l}\text { Potassium metabisulfite tolerance } \\
\text { (halo size/colony size, } \mathrm{cm} \text { ) }\end{array}$} \\
\hline & $10 \%$ & $12 \%$ & $15 \%$ & $20 \%$ & & & \\
\hline SCMA01 & 1.65 & 1.50 & 1.20 & 1.70 & 1.40 & 1.58 & 1.89 \\
\hline SCMA02 & 1.55 & 1.80 & 1.70 & 1.95 & 2.00 & 2.21 & 1.60 \\
\hline SCMA03 & 1.73 & 2.00 & 2.05 & 1.95 & 3.95 & 5.10 & 1.47 \\
\hline SCMA05 & 1.46 & 1.78 & 2.00 & 2.29 & 6.18 & 7.56 & 1.72 \\
\hline SCMA06 & 1.50 & 2.30 & 2.05 & 2.70 & 6.83 & 8.88 & 2.08 \\
\hline SCMA16 & 1.52 & 2.00 & 1.74 & 2.00 & 4.55 & 5.92 & 1.88 \\
\hline SCMA17 & 1.45 & 1.50 & 2.00 & 2.15 & 3.90 & 5.04 & 1.51 \\
\hline SCMA18 & 1.56 & 1.74 & 1.74 & 1.72 & 4.12 & 5.36 & 2.23 \\
\hline SCMA19 & 1.40 & 1.57 & 1.95 & 2.00 & 4.28 & 4.98 & 1.93 \\
\hline SCMA23 & 1.12 & 2.15 & 1.96 & 1.95 & 3.57 & 4.79 & 1.73 \\
\hline SCMA38 & 1.33 & 1.50 & 1.27 & 1.20 & 1.13 & 1.45 & 2.09 \\
\hline SCMA39 & 2.74 & 2.40 & 2.11 & 2.48 & 2.05 & 2.84 & 2.07 \\
\hline SCMA40 & 2.37 & 2.20 & 2.25 & 2.73 & 1.92 & 2.77 & 1.51 \\
\hline SCMA47 & 2.69 & 2.17 & 2.00 & 2.80 & - & 0.88 & 1.81 \\
\hline SCMA53 & 2.86 & 2.14 & 2.43 & 2.67 & - & 0.19 & \\
\hline
\end{tabular}

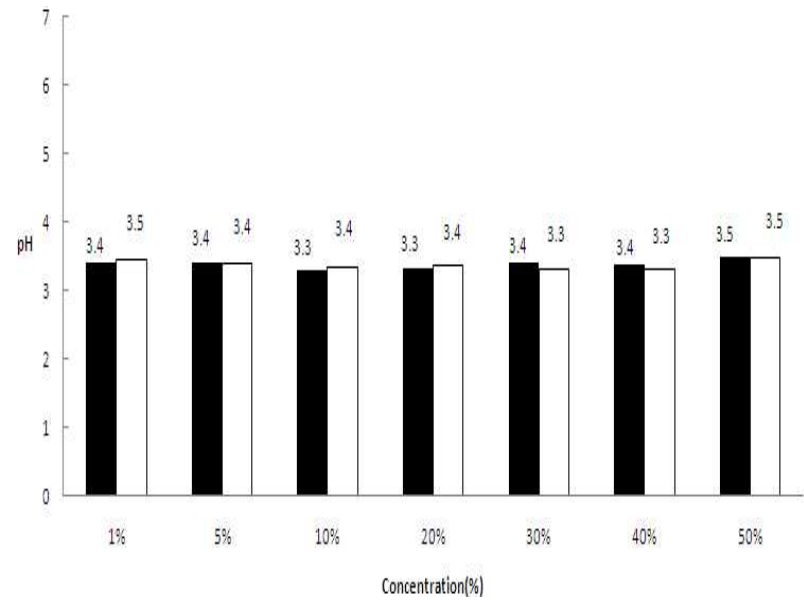

Fig. 5. $\mathrm{pH}$ change in the fermentation solution at each concentration of the fruits of Cudrania tricuspidata. $\mathbf{\square}$, Cudrania tricuspidata+SCMA5; $\square$, Cudrania tricuspidata+SCMA6.

할 때 배양액의 산도가 더 높았다는 결과를 보고하였다. 따라서, $5 \%(\mathrm{v} / \mathrm{v})$ 의 ethanol을 첨가하고 꾸지뽕 열매 즙액이 $40 \%(\mathrm{v} / \mathrm{v})$ 인 배지를 제조하여 $25^{\circ} \mathrm{C}$ 에서 $200 \mathrm{rpm}$ 으로 교반하 며 초산균을 배양하는 것을 발효식초 제조 조건에 적합함을 확인하였으며, 결정된 배양조건으로 최종 검증한 발효양상 은 Fig. 8과 같았다.

\section{관능평가}

$A$ pasteurianus 2종을 이용하여 발효액을 제조하여 관능

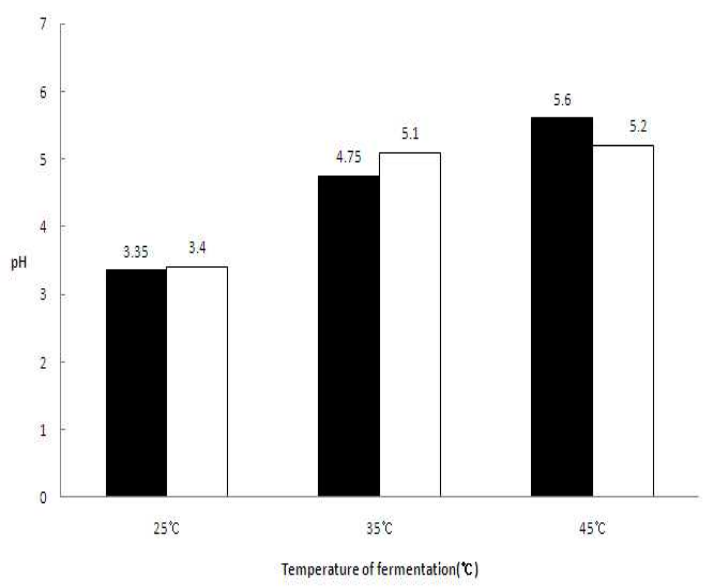

Fig. 6. $\mathrm{pH}$ change in the fermentation solution at each fermentation temperature. $\square$, Cudrania tricuspidata+SCMA5; $\square$, Cudrania tricuspidata+SCMA6.

평가를 실시한 결과, 색에서는 두 균주간 차이는 없었으며, 향과 전체적인 기호도에서 $A$ pasteurianus SCMA06 균주가 높은 선호도를 보였다. 신맛 부분에서도 $A$ pasteurianus $\mathrm{SCMA06}$ 균주가 신맛의 강도가 더 강하게 느껴지는 것으로 평가되었다(Table 3).

\section{이화학적 특성}

꾸지뽕 열매 발효액의 품질 분석을 위하여 $\mathrm{pH}$, 산도 및 당도를 발효시간을 $0,24,48,72$ 시간으로 하여 측정한 결과, 발효액은 발효 24시간 후에는 큰 변화를 보이지 않았으나, 


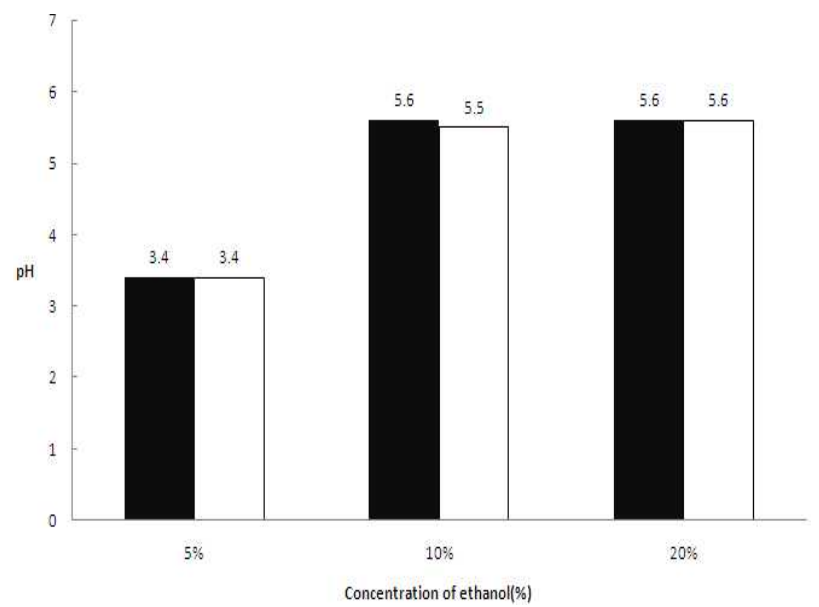

Fig. 7. $\mathrm{pH}$ change in the fermentation solution at each concentration of ethanol. $\square$, Cudrania tricuspidata+SCMA5; $\square$, Cudrania tricuspidata+SCMA6.

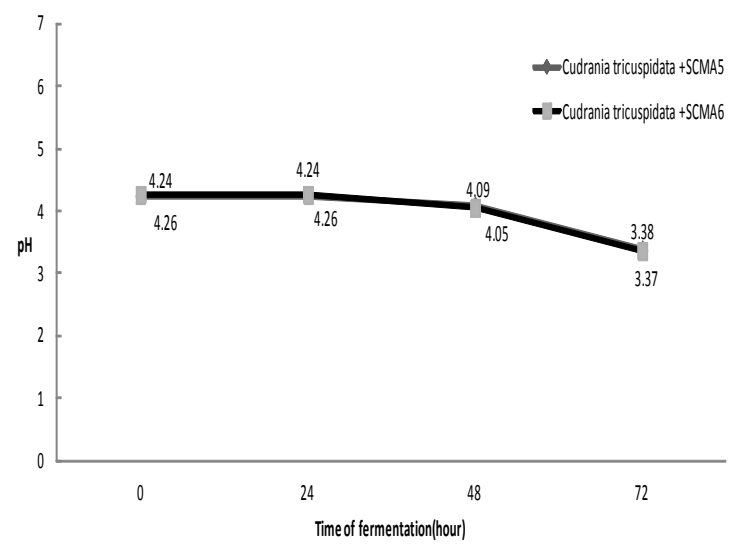

Fig. 8. $\mathrm{pH}$ change in the fermentation solution during the fermentation period.

Table 3. Sensory characteristics of vinegar

\begin{tabular}{ccc}
\hline No. & $A$ pasteurinus SCMA5 & $A$ pasteurinus SCMA6 \\
\hline Color & $3.54 \pm 0.66^{1)}$ & $3.69 \pm 0.63$ \\
Flavour & $3.46 \pm 0.66$ & $4.12 \pm 0.63$ \\
Sour taste & $3.85 \pm 0.74$ & $4.17 \pm 0.57$ \\
Overall preference & $3.82 \pm 0.38$ & $4.50 \pm 0.73$ \\
\hline
\end{tabular}

1)5 point Likert scale: 1-extremely dislike,5-extremely like, ${ }^{2} 5$ point Likert scale: 1-extremelylow, 5-extremely high. Each value represents the mean \pm S.D

48 시간 이후 점차 $\mathrm{pH}$ 가 4.0 까지 감소하고, 그에 따른 산도 의 증가와 생균수의 증가를 확인할 수 있었으며, 72 시간에 는 $\mathrm{pH}$ 3.4까지 감소하는 것을 확인하였다(Table 4). 발효액 에서의 당도는 시간에 따른 차이가 거의 없었다.

\section{미생물학적 특성}

미생물학적 특성을 분석한 결과, 진균과 식중독 미생물
Table 4. Physico-chemical and microbic properties of vinegar

\begin{tabular}{ccccccc}
\hline Sample & $\begin{array}{c}\text { Period } \\
\text { (hour) }\end{array}$ & $\mathrm{pH}$ & $\begin{array}{c}\text { Acidity } \\
(\%)\end{array}$ & ${ }^{\circ}$ Brix & $\begin{array}{c}\text { Total aerobic count } \\
\text { (log CFU/mL) }\end{array}$ & $\begin{array}{c}\text { Pathogenic } \\
\text { microorganism }\end{array}$ \\
\hline \multirow{4}{*}{ vinegar } & 0 & 4.7 & 0.14 & 7.0 & 4.86 & $\mathrm{ND}^{2)}$ \\
& 24 & 4.3 & 0.18 & 7.0 & 5.26 & $\mathrm{ND}$ \\
& 48 & 4.1 & 0.20 & 7.0 & 6.26 & $\mathrm{ND}$ \\
& 72 & 3.4 & 0.64 & 6.5 & 7.69 & $\mathrm{ND}$
\end{tabular}

${ }^{1)}$ Pathogenic microorganism : E. coli, Samonella. spp, E. coli 0157:H7, Listeria monocytogenes, Staphylococcus aureus, Clostridium perfringenes, Bacillus cereus ${ }^{2} \mathrm{ND}$ : Not detected

은 꾸지뽕 열매 초산균 발효액에서 검출되지 않았고, 총균 수는 $10^{6} \mathrm{CFU} / \mathrm{g}$ 이 검출되었다. 분석결과는 Table 4 와 같다. 이는 꾸지뽕 열매 발효액의 낮은 $\mathrm{pH}$ 로 인해 진균과 식중독 미생물이 생육의 저해를 받았을 것으로 추측할 수 있다. Woo 등(32)은 현미식초와 감식초가 Bacillus subtilis, Staphylococcus aureus, Micrococcus luteus, Escherichia coli, 및 Vibrio parahaemoluticus를 억제했다고 보고하였으며, 원 재료의 항균물질 이외에도 초산에 의한 항균효과를 나타낸 것을 확인하였다.

\section{$\mathrm{DPPH}$ radical 소거능 활성}

DPPH radical은 아스코르브산 및 토코페롤, polyhydroxy 방향족 화합물, 방향족 아민류에 의해 전자나 수소를 받아 환원되어 안정한 분자를 형성하게 될 때, 보라색이 탈색되 어지는 원리를 이용하여 다양한 천연소재로부터 항산화 물질을 탐색하기 위해 많이 이용되고 있으며, 비교적 짧은 시간 내에 간단하게 항산화능을 측정할 수 있어 널리 사용 되고 있는 방법이다(27). 최종 선정된 $40 \%(\mathrm{v} / \mathrm{v})$ 꾸지뽕 발효 식초의 DPPH 라디컬 소거활성은 Fig. 9에 나타내었다. 발 효식초는 시간이 지남에 따라 DPPH radical 활성이 증가하 는 것으로 나타났으며 양성 대조구인 토코페롤 $(1 \%(\mathrm{v} / \mathrm{v}))$ 에 비해 낮은 활성을 보였지만 균주를 접종하지 않은 대조구에 비해 높은 활성(53.02 $\pm 0.78 \%)$ 을 나타내었다. Jung과 Park 등(28)의 결과와 비교하여 활성은 낮은 편이지만 발효액은 발효시간이 진행될수록 DPPH radical 활성이 증가한다는 내용과 일치하는 결과를 보여주었다.

\section{a-Glucosidase inhibition(AGI) 활성}

a-Glucosidase는 a-amylase에 의해 분해된 당질을 최종적 인 단당류로 전환시킨다. 이러한 효소의 활성 저해는 당질 가수분해와 흡수과정을 지연시킴으로 식후 당 농도를 제한 한다고 보고되고 있다(29). 또한 a-Glucosidase 저해제는 제 2 형 당뇨와 같은 당질 관련 질병을 위한 치료제 개발에 유용하다고 제시하고 있다(30). 본 연구에서는 최종 선정된 $40 \%(\mathrm{v} / \mathrm{v})$ 꾸지뽕 열매 발효 식초의 a-Glucosidase 저해능을 Fig. 10에 나타내었다. Positive control로 사용된 acarbose는 $75.31 \pm 1.22 \%$ 의 저해능을 나타냈으며, 꾸지뽕 발효식초는 
발효시간이 지남에 따라 저해능은 높아져 72시간 발효 후 엔 $91.40 \pm 2.43 \%$ 의 저해능을 나타내었다. Park(31)에 따르 면 발효 꾸지뽕 잎이 생잎이나 덖음한 것에 비하여 내당능 과 $a-G l u c o s i d a s e$ 저해활성이 가장 큰 것으로 나타나 발효가 진행될수록 a-Glucosidase 저해능이 높아지는 본 연구결과 와 일치하는 결과를 보여주었다.

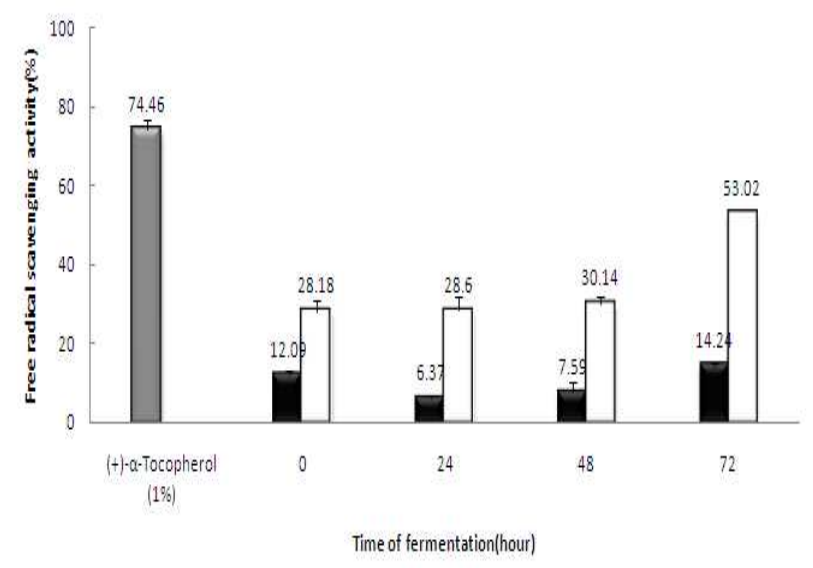

Fig. 9. Free radical scavenging activities of Cudrania tricuspidata vinegar.

$\boldsymbol{\square}$, control; $\square$, vinegar; $\square,(+)-a-$ Tocopherol(1\%). The data represent the mean $\pm \mathrm{SD}$ of at least three independent experiments. Different alphabetical letters mean significantly different at $\mathrm{p}<0.05$.

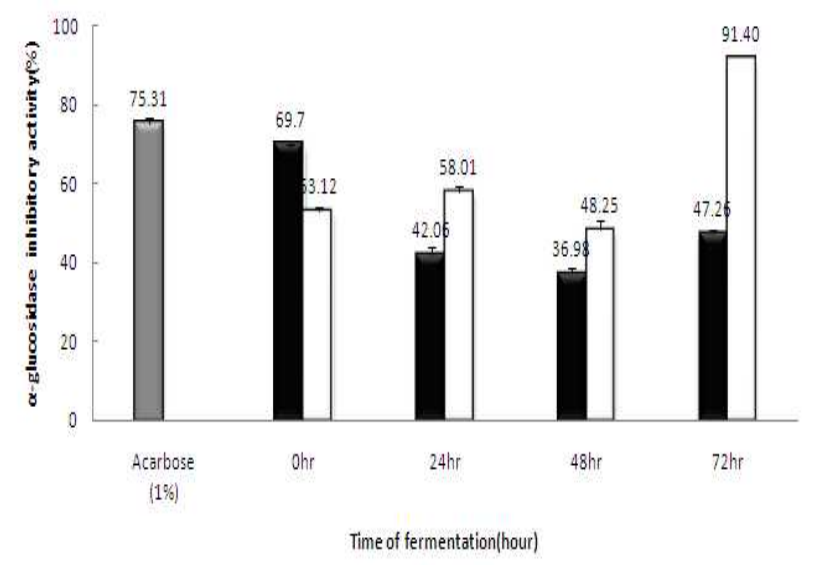

Fig. 10. a-glucosidase inhibition activity of Cudrania tricuspidata vinegar.

$\square$, control; $\square$, vinegar; $\square$, acarbose(1\%). The data represent the mean \pm SD of at least three independent experiments. Different alphabetical letters mean significantly different at $\mathrm{p}<0.05$.

\section{요 약}

꾸지뽕 열매의 부가가치를 증대하기 위해 꾸지뽕 발효식 초를 제조하고 그의 발효조건을 확립하였다. 전통발효식품
으로부터 초산내성, 초산 고생산능, ethanol 내성 및 아황산 내성이 우수한 49종의 초산 균주를 분리하였고, $16 \mathrm{~S}$ rRNA 유전자 염기서열의 해독 결과, Acetobacter indonesiensis, $A$ cerevisiae, $A$ orientalis, $A$ tropicalis, $A$ fabarum, $A$ pasteurianus 및 $A$ syzygii으로 동정되었다. 이들 중 GRAS 균주인 $A$ pasteurianus SCMA5와 SCMA6를 발효 균주로 최종 선정하였다. 최적 발효는 꾸지뽕 열매 함량이 $40 \%(\mathrm{v} / \mathrm{v})$ 인 즙액과 $5 \%(\mathrm{v} / \mathrm{v})$ ethanol을 첨가하여 $25^{\circ} \mathrm{C}$ 에서 72시간 발효가 가장 적절하였다. 관능평가 결과, SCMA06 균주를 적용한 발효액의 선호도가 SCMA05 균주를 적용한 발효액보다 높았다. SCMA06 균주를 사용한 발효식초에서 항산화 능력을 측정하는 DPPH 라디컬 소거활성의 경우 대조구에 비해 $53.02 \pm 0.78 \%$ 이상 높게 나타났고, 항당뇨 능력을 측정하는 $\mathrm{AGI}$ 활성은 발효 72 시간에 $91.40 \pm 2.43 \%$ 저해능을 보여 시판중인 acarbose보다 활성이 높았다. 이번 연구는 꾸지뽕 열매를 활용한 발효식초 제조를 위한 산업화 연구에 기여할 수 있을 것이다.

\section{감사의 글}

본 연구는 농촌진흥천 연구사업(과제번호 PJ00999002) 와 2013년 지역특화산업육성(기술개발)사업(과제번호 R0002266)의 지원에 의해 수행되었습니다.

\section{References}

1. Sengun IY, Karabiyikli S (2011) Importance of acetic acid bacteria in food industry. Food Control, 22, 647-656

2. Raspor P, Goranovic D (2008) Biotechnological applications of acetic acid bacteria. Crit Rev Biotechnol, $28,101-124$

3. González Á, Mas A (2011) Differentiation of acetic acid bacteria based on sequence analysis of 16S-23S rRNA gene internal transcribed spacer sequences. Int J Food Microbiol, 147, 217-222

4. Park MH, Lee JO, Lee JY, Yu SJ, Ko YJ Kim YH, Ryu CH (2005) Isolation and characteristics of acetic acid bacteria for persimmon vinegar fermentation. J Korean Soc Food Sci Nutr, 34, 1251-1257

5. Kang SK, Jang MJ, Kim YD (2006) Isolation and culture conditions of Acetobacter sp. for the production of citron (Citrus junos) vinegar. Korean J Food Preserv, 13, 357-362

6. Han WC, Ji SH, Surh J, Kim MH, Lee JC, Jang KH (2010) Characterization of vinegar using Rubus 
crataegifolius and Rosa rugosa Thunb. J East Asian Soc Dietary Life, 20, 582-588

7. Kang BH, Shin EJ, Lee SH, Lee DS, Hur SS, Shin KS, Kim SH, Son SM, Lee JM (2011) Optimization of the acetic acid fermentation condition of apple juice. Korean J Food Preserv, 18, 980-985

8. Mo HW, Jung YH, Jeong JS, Choi KH, Choi SW, Park CS, Choi MA, Kim ML, Kim MS (2013) Quality characteristics of vinegar fermented using omija (Schizandra chinensis Baillon). J Korean Soc Food Sci Nutr, 42, 441-449

9. Yi MR, Hwang JH, Oh YS, Oh HJ, Lim SB (2014) Quality characteristics and antioxidant activity of immature citrus unshiu vinegar. J Korean Soc Food Sci Nutr, 43, 250-257

10. Matsutani M, Hirakawa H, Yakushi T, Matsushita K (2010) Genome-wide phylogenetic analysis of Gluconobacter, Acetobacter, and Gluconacetobacter. FEMS Microbiol Lett, 315, 122 - 128

11. Son HU, Lee SH (2013) Comparison of a-glucosidase inhibition by Cudrania tricuspidata according to harvesting time. Biomed Rep, 1, 624-628

12. Lee EG, Yun HJ, Lee SI, Yoo WH (2010) Ethyl acetate fraction from Cudrania tricuspidata inhibits IL-1 $\beta$ -stimulated osteoclast differentiation through downregulation of MAPKs, c-Fos and NFATc1. Korean J Intern Med, 25, 93-100

13. Kim MS, Kim IA, Ko YJ, Jeong JA, Kim JE, Song BJ, Lim WB, Lim HS, Park JI, Kim SY, Choi HR, Kim OJ (2009) Methanol extract of leaves from Cudrania tricuspidata effects in HT-29 colorectal adenocarcinoma. Korean J Oral maxillofac Pathol, 33, 19-26

14. Yang GB, Lee KJ, Lee MH, Ham IH, Choi HY (2012) Inhibition of lipopolysaccharide-induced nitric oxide and prostaglandin E2 production by chloroform fraction of Cudrania tricuspidata in RAW 264.7 macrophages. BMC Complement Altern Med, 12, 250

15. Zhang, Z, Schwarz, S, Wagner, L, Miller, W (2000) A greedy algorithm for aligning DNA sequences. J Comput Biol, 7, 203-214

16. Thomson, JD, Higgins, DG, Gibson, TJ (1994) CLUSTALW: improving the sensitivity of progressive multiple sequence alignment through sequence weighing position-specific gap penalties and weight matrix choice. Nucleic Acids Res, 22, 4673-4680

17. Tamura K, Peterson D, Peterson N, Stecher G, Nei M, Kumar S (2011) MEGA5 : Molecular evolutionary genetics analysis using maximum likelihood, evolutionary distance, and maximum parsimony methods. Mol Biol Evol, 28, 2731-2739

18. Blois MS (1958) Antioxidant determinations by the use of a stable free radical. Nature, 181, 1990-1200

19. Watanabe J, Kawabata J, Kurihara H, Niki R (1997) Isolation and identification of a-glucosidase inhibitors from tochucha (Eucommia ulmoides). Biosci Biotech Biochem, 61, 177-178

20. Park SY, Chae KS, Son RH, Jung HY, Im YR, Kwon JW (2012) Quality characteristics and antioxidant ativity of Bokbunja (Black raspberry) vinegars. Food Eng Prog, $16,340-346$

21. Keun JH (1999) Studies on garlic and pumpkin vinegar. Korean J Food and Nutr, 12, 518-522

22. Kim SD, Jang KS, Kim MK (1994) Fermentation of apple vinegar in the farmhouse. J East Asian Soc Dietary life, 4, 79-90

23. Kim YT, Seo Ki, Jung YJ, Lee YS, Shim KH (1997) The production of vinegar using citron (Citrus junos Seib) juice. J East Asian Soc Dietary life, 7, 301-307

24. Lee GD, Kwon SH, Lee MH, Kim SK, Kwon JH (2002) Monitoring on alcohol and acetic acid fermentation properties of muskmelon. Korean J Food Sci Technol 24, 30-36

25. Lee GD, Jeong YJ, Seo JH, Lee JM (2000) Monitoring on alcohol and acetic acid fermentation of potatoes using response surface methdology. J Korean Soc Food Sci Nutr. 29, 1062-1067

26. Shin JH, Ryu CH, Cho SH (2002) Development of vinegar and vinegar-containing beverage from carrots. J Agr and Life Sci, 36, 39-46

27. Que F, Mao L, Zhu C, Xie G (2006) Antioxidant properties of Chineses yellow wine, its concentrate and volatiles. LWT-Food Sci Technol, 39, 111-117

28. Jung KA, Park CS (2012) Physiological activities of fermented garlic broth during fermentation. Korean $\mathbf{J}$ Food Preserv, 19, 406-412

29. Shinde J, Taldone T, Barletta M, Kunaparaju N, Hu B, Kumar S, Placido J, William ZS (2008) a-Glucosidase inhibitory activity of Syaygium cumini (Linn.) Skeels seed kernel in vitro and in Goto-Kakizaki (GK) rats. Carbohyd Res 343, 1278-1281

30. Baron $\mathrm{AD}$ (1998) Postprandial hyperglycemia and a -glucosidase inhibitors. Diabetes Res Clin Pr, 40, 51-55

31. Park BH (2008) Studies on quality characteristics and anti-diabetic effect of fermented mulberry (Cudrania 
tricuspidata) leaves. MS Thesis, Catholic University of Deagu, Korea, p 41-43

32. Woo SM, Jang SY, Kim OM, Youn KS, Jeong YJ (2004)
Antimicrobial effects of vinegar on the harmful food-born organisms. Korean J Food Preserv, 11, 117-121 